\title{
Changing Trends of Commonly Used Intensive Care Unit Antibiotics Due to Differential Membrane Permeability in Resistant Escherichia coli Collected in EASE Programme
}

\author{
Manu Chaudhary and Anurag Payasi*
}

Department of Cell Culture and Molecular Biology, Venus Medicine Research Centre, Baddi, H.P., India

\begin{abstract}
In order to understand resistance pattern of Escherichia coli clinical isolates, the outer membrane permeability trend of different antibiotics was studied. The outer membrane permeability of Elores was compared with other commonly used intensive care unit (ICU) drugs being used in the treatment of various infections caused by resistant E. coli. A total of fifty three isolates collected under EASE programme from North Indian hospitals, fifteen extended spectrum $\beta$-lactamases (ESBL) positive clinical isolates of $E$. coli were included in the study. Michaelis constants $(\mathrm{Km})$ and maximal rates of substrate hydrolysis (Vmax) were determined from Lineweaver-Burk plot. Permeability coefficient was determined using the method described by Zimmermann and Rosslet. Elores demonstrated the lowest Vmax/Km ratio further indicating its lower affinity (high Km 209.9 $\pm 17.4 \mu \mathrm{M}$ ) towards $\beta$-lactamase or more stability against $\beta$-lactamase enzyme. The other comparator drugs including penems, colistin, $\beta$-lactam and $\beta$-lactamase inhibitor combinations exhibited three to ten folds higher $V \max / \mathrm{Km}$ ratio compared to Elores indicating very high affinity for $\beta$-lactamase induced degradation. Elores penetrated the outer membrane of ESBL producing resistant $E$. coli with permeability coefficient approximately 1.8, 2.2, 6.9, 2.5 and 2.3 times higher than imipenem plus cilastatin, meropenem, colistin, cefoperazone plus sulbactam, piperacillin plus tazobactam, respectively. The increased penetration of the Elores leads to higher periplasmic concentration of the drug resulting in reduced MIC. Our results clearly demonstrated that Elores exhibited the highest permeability coefficient, enhanced penetration, greater stability and periplasmic concentration leading to higher susceptibility towards resistant $E$. coli compared to other drugs. Therefore, Elores can be considered as an empiric drug of choice for the treatment of infections caused by $E$. coli positive with ESBL.
\end{abstract}

Keywords: $\beta$-lactam; Clinical isolates; Escherichia coli; Elores; Enzyme kinetics; Elores antimicrobial susceptibility evaluation programme

\section{Introduction}

Antibiotic resistance is becoming a global threat with rapidly and alarmingly decreasing antibiotic response. The problem is more prevalent in common pathogens like Escherichia coli which are opportunistic and adopt different mechanisms to exhibit resistance. $\beta$-lactam antibiotics such as penicillin, cephalosoprins, carbapenems are potent and widely used antibiotics in intensive care units (ICUs). They inhibit the growth of sensitive bacteria by deactivating enzymes located in the bacterial cell membrane, which are involved in the cell wall synthesis [1]. However, in recent years, bacterial resistance to $\beta$-lactam antibiotics has risen dramatically $[2,3]$. This resistance results mainly from the sensitivity of the target enzymes, properties and concentration of the periplasmic $\beta$-lactamase, permeability of the outer membrane and efficiency of the efflux pump [4]. Of these, outer membrane permeability and $\beta$-lactamase are key factor for the resistance of bacteria to antibiotics [5]. Permeability plays a key role in antibiotic activity, as the antibiotics have to penetrate the outer membrane before they reach their targets at the surface of the bacterial inner membrane. Rapid penetration of antibiotics is an important factor affecting their bactericidal activity $[6,7]$.

In $E$. coli, outer membrane permeability is regulated by the balance of porin proteins. Porins are outer membrane proteins that allow the diffusion of a few antibiotics across the outer membrane [8]. Three mechanisms have been suggested for the uptake of antibiotics across the outer membrane of gram negative bacteria [5]. First is hydrophilic pathway, which involves the passive diffusion of small hydrophilic antibiotics through the porins. It has been believed that in $E$. coli
$\mathrm{OmpF}$ and $\mathrm{OmpC}$ porins are the main pathway for antibiotic diffusion $[9,10]$. However, OmpC and $\mathrm{OmpF}$ porins homologous have been described for other members of Enterobacteriaceae including Klebsiella pneumoniae $[8,11]$. Second is hydrophobic uptake pathway, in which hydrophobic antibiotics partition into the outer membrane bilayer [7]. Third is self-promoted uptake of antibiotics, in which polycationic antibiotics interact with a site on the outer membrane at which $\mathrm{Mg}^{2+}$ non-covalently cross-bridges adjacent lipo-polysaccharide molecules [12]. The third mechanism of drug uptake is widely distributed in the microorganisms $[12,13]$. In recent years antibiotic resistance due to loss of porin channels, which reduce the outer membrane permeability to antibiotics, has been reported [14]. Although, membrane permeability is widely affected by expression of cellular transporters, OmpF and OmpC, we did not study the expression pattern of these transporters in these clinical isolates.

Above literature indicates that antibiotic resistance because of membrane permeability has been increasing. Therefore, in order to

*Corresponding author: Anurag Payasi, Venus Medicine Research Centre, Hil Top Industrial Estate, Bhatoli Kalan, Baddi, H.P. - 173205 India, Tel: 91-1795302068; Fax: 91-1795-302133; E-mail: ccmb@venusremedies.com

Received June 10, 2013; Accepted September 04, 2013; Published September 09, 2013

Citation: Chaudhary M, Payasi A (2013) Changing Trends of Commonly Used Intensive Care Unit Antibiotics Due to Differential Membrane Permeability in Resistant Escherichia coli Collected in EASE Programme. J Microb Biochem Technol 5: 084-087. doi:10.4172/1948-5948.1000105

Copyright: (C) 2013 Chaudhary M, et al. This is an open-access article distributed under the terms of the Creative Commons Attribution License, which permits unrestricted use, distribution, and reproduction in any medium, provided the original author and source are credited 
understand resistance behavior of $E$. coli clinical isolates to commonly used ICU drugs, the outer membrane permeability was studied under Elores Antimicrobial Susceptibility Evaluation (EASE) programme.

\section{Materials and Methods}

\section{Antibiotics}

A novel antibiotic adjuvant entity, (AAE) comprising ceftriaxone sodium, and sulbactam sodium with non antibiotic adjuvant ethylenediaminetetraacetic acid (EDTA), herein after referred to as Elores ( $1 \mathrm{~g}$ ceftriaxone and $0.5 \mathrm{~g}$ sulbactam), piperacillin plus tazobactam (4 g piperacillin, $0.5 \mathrm{~g}$ tazobactam), cefoperazone plus sulbactam (1 g cefoperazone, $1 \mathrm{~g}$ sulbactam), imipenem plus cilastatin (0.5 g imipenem, $0.5 \mathrm{~g}$ cilastatin) and meropenem $(\mathrm{g})$, and colistin $(0.15 \mathrm{~g})$ were used in the study.

\section{Bacterial strains}

A total of fifty three clinical isolates were collected under EASE (Elores Antimicrobial Susceptibility Evaluation) programme from public and private hospitals of Delhi national capital region (NCR) region, India out of which fifteen extended spectrum $\beta$-lactamases (ESBL) positive clinical isolates (CI) of E. coli were taken for the study. These isolates were re-identified using standard bacteriological techniques [15]. The bacterial suspension was used as the inoculum at a concentration of 106 colony-forming units ( $\mathrm{cfu} / \mathrm{ml})$. E. coli (ATCC 35218) encoding TEM-1 $\beta$-lactamase was used as a positive control (PC).

\section{Minimum inhibitory concentration (MIC) testing}

MIC study was carried out by serial twofold dilution according to CLSI methods [16].

\section{$\beta$-lactamase studies}

$\beta$-lactamase assay was carried out by the micro-iodometric method as described earlier [17]. In brief, $10 \mathrm{ml}$ of exponentially growing cultures of E. coli were harvested by centrifugation at $5000 \mathrm{rpm}$ for 5 minutes at $25^{\circ} \mathrm{C}$ and re-suspended in $1 \mathrm{ml}$ of phosphate buffer saline (PBS) (10mM, pH 7.4), a portion of this suspension was used directly in assaying the $\beta$-lactamase activity of intact cells. The remaining part of the cell suspension was provided with $10 \%$ SDS and incubated at 37 $\pm 2^{\circ} \mathrm{C}$ for 2 hours. Following incubation, the solution was centrifuged at $7800 \mathrm{rpm}$ for 10 minutes at $4^{\circ} \mathrm{C}$. The resultant supernatant was then applied to a HiTrap zinc chelating column (Pharmacia). $\beta$-lactamase bound strongly to the column while other periplasmic proteins eluted out with buffer A (Sodium acetate, $\mathrm{pH} 8.0$ containing $400 \mathrm{mM}$ $\mathrm{NaCl})$. $\beta$-lactamase was eluted using a linear gradient of buffer $\mathrm{B}$ (100 $\mathrm{mm}$ Sodium acetate, pH 4.0 containing $400 \mathrm{~mm} \mathrm{NaCl}$ ). Fractions containing $\beta$-lactamase activity were pooled and used for the kinetic study. The concentration of enzyme used for kinetic analysis with various substrates is mentioned in Table 1 .

\section{Determination of velocities of $\beta$-lactam hydrolysis by intact cells and sonicated cells}

For determining the velocity of $\beta$-lactam hydrolysis different concentrations of substrate (drugs) were pre-incubated in water bath in 2 sets for $5 \mathrm{~min}$ at $37^{\circ} \mathrm{C}$, and then the reaction was started by adding 1 $\mathrm{ml}$ of intact cells in one set and enzyme cell suspensions in another set. $1 \mathrm{ml}$ of starch iodine reagent $(100 \mu \mathrm{l}$ of $0.08 \mathrm{M}$ iodine, $3.2 \mathrm{M}$ potassium iodide with $80 \mathrm{ml}$ of $0.25 \mathrm{M}$ sodium tungstate in $1 \mathrm{~N}$ acetic acid, $20 \mathrm{ml}$ of $2 \%(\mathrm{w} / \mathrm{v})$ soluble starch dissolved in $1 \mathrm{~N}$ acetic acid) was added to each set and the reaction volume was made upto $3 \mathrm{ml}$ with $10 \mathrm{mM}$ PBS buffer. The absorbance was measured at $623 \mathrm{~nm}$ initially against $10 \mathrm{mM}$ $\mathrm{PBS}$ and the reaction mixture was incubated for $20 \mathrm{~min}$ at $37^{\circ} \mathrm{C}$ and the absorbance was again measured against PBS at $623 \mathrm{~nm}$. $\beta$-lactamase action was measured as the decolorization of starch iodine reagent after 20 minutes.

\section{Kinetic study}

Reaction-rate substrate concentration relationship was studied with various drugs in the range of 5 to $400 \mu \mathrm{M}$ (Table 1). Hyperbolic substrate saturation curves indicated Michaelin kinetics. The double reciprocal (Lineweaver-Burk) plots of the data were plotted to calculate $\mathrm{Km}$ and Vmax of each drug.

\section{Permeability coefficient study}

Permeability coefficient was determined using the method described previously [18]. At a given antibiotic concentration outside the $\beta$-lactamase synthesizing cells, So, a steady state is rapidly established at which rate of antibiotic diffusion and velocity of $\beta$-lactam hydrolysis are equal. At a steady state, antibiotic concentration inside the outer membrane, Se, is calculated by:

$$
\left(\mathrm{V}_{\text {intact }} \cdot \mathrm{K}_{\mathrm{m}}\right) /\left(\mathrm{V}_{\text {max }}-\mathrm{V}_{\text {intact }}\right)
$$

Permeability barrier, $\mathrm{C}$ is calculated by:

$$
\begin{aligned}
& \mathrm{C}=\mathrm{Se} \cdot \mathrm{V}_{\text {max }} \\
& \mathrm{Se}+\mathrm{Km}(\mathrm{So}-\mathrm{Se})
\end{aligned}
$$

where; C, permeability (diffusion) parameter; Vmax, rate of substrate hydrolysis; Se, antibiotic concentration inside the outer membrane; $\mathrm{K}_{\mathrm{m}}$, Michaelis constant; So, initial antibiotic concentration; Vintact, velocity of intact cells.

\begin{tabular}{|c|c|c|c|c|c|c|c|c|}
\hline \multirow[t]{2}{*}{ Drugs } & \multicolumn{2}{|c|}{$\begin{array}{l}\text { Substrate concentration } \\
\text { range }(\mu \mathrm{M})\end{array}$} & \multicolumn{2}{|c|}{$\begin{array}{l}\text { Enzyme concentration } \\
\text { range }(\mu \mathrm{M})\end{array}$} & \multicolumn{2}{|c|}{$\begin{array}{l}\mathbf{V}_{\max } \\
\text { (units/mg protein) }\end{array}$} & \multicolumn{2}{|l|}{$\mathrm{K}_{\mathrm{m}}(\mu \mathrm{M})$} \\
\hline & PC & $\mathrm{Cl}$ & PC & $\mathrm{Cl}$ & PC & $\mathrm{Cl}$ & PC & $\mathrm{Cl}$ \\
\hline Elores & $20-400$ & $20-400$ & $0.5-2.0$ & $0.5-2.0$ & $273.1 \pm 21.7$ & $273.5 \pm 20.7$ & $210.2 \pm 18.5$ & $209.9 \pm 17.4$ \\
\hline $\begin{array}{l}\text { Imipenem } \\
\text { plus cilastatin }\end{array}$ & $20-400$ & $20-400$ & $0.5-2.0$ & $0.5-2.0$ & $198.7 \pm 25.4$ & $299.8 \pm 25.7$ & $66.7 \pm 6.2$ & $66.1 \pm 6.4$ \\
\hline Meropenem & $20-400$ & $20-400$ & $0.5-2.0$ & $0.5-2.0$ & $303.1 \pm 27.1$ & $304.4 \pm 26.8$ & $60.6 \pm 5.2$ & $59.4 \pm 5.4$ \\
\hline Colistin & $5-150$ & $5-150$ & $0.5-2.0$ & $0.5-2.0$ & $329.8 \pm 24.8$ & $331.1 \pm 27.1$ & $26.0 \pm 1.7$ & $25.1 \pm 1.8$ \\
\hline $\begin{array}{l}\text { Cefoperazone plus } \\
\text { sulbactam }\end{array}$ & $5-150$ & $5-150$ & $0.5-2.0$ & $0.5-2.0$ & $328.8 \pm 28.0$ & $329.4 \pm 3.1$ & $36.9 \pm 3.5$ & $36.2 \pm 3.5$ \\
\hline Piperacillin plus tazobactam & $5-150$ & $5-150$ & $0.5-2.0$ & $0.5-2.0$ & $328.2 \pm 29.0$ & $328.8 \pm 28.4$ & $37.2 \pm 3.4$ & $36.6 \pm 3.4$ \\
\hline
\end{tabular}

\section{Protein estimation}

Protein was assayed according to the method of Lowry et al. [19].

Table 1: Kinetic parameters of TEM-1 $\beta$-lactamases for Elores and other drugs. 


\section{Results and Discussion}

\section{Comparison of Vintact/Vsonicated at different antibiotic concentrations}

Results of the velocity of $\beta$-lactam hydrolysis with different substrate concentrations are shown in Figure 1 for both positive control and clinical isolates. Results of this study revealed that both Vintact/Vsonicated are constant from 0.01 to $0.15 \mathrm{mM}$ and then increase upto $0.2 \mathrm{mM}$. However, further increasing the concentrations of drugs it remained constant suggesting Vintact/Vsonicated depends on So. Interestingly, it has also been observed that Elores exhibited the maximum absorbance indicating the least degradation and maximum stability against ESBL enzyme produced in E.coli resistant isolates. These findings are in agreement with results reported earlier for the E. coli $[18]$.

\section{$\beta$-lactamase studies}

Results of the kinetic study are presented in Table 1. This result revealed that Elores exhibited low affinity and high $\mathrm{Km}, 210.2 \pm 18.5$ and $209.9 \pm 17.4 \mu \mathrm{M}$ for positive control and clinical isolates respectively, towards E. coli $\beta$-lactamase producing strains. Conversely, both penems, imipenem plus cilastatin and meropenem, colistin, and $\beta$-lactam plus $\beta$-lactamase inhibitor (BL $+\mathrm{BLI})$ combinations, cefoperazone plus sulbactam, piperacillin plus tazobactam exhibited high affinity (low $\mathrm{Km}$ ) for positive control and clinical isolates suggesting these drugs are more rapidly hydrolyzed by ESBL (Table 1 ). Vmax values obtained for Elores for positive control and clinical isolates were $273.1 \pm 21.7$ and $273.5 \pm 20.7$ units/mg protein. The Vmax of other drugs are shown in Table 1. The $\mathrm{Vmax} / \mathrm{Km}$ ratio is designated as physiological efficiency indicating the capability of $\beta$-lactamase to hydrolyze a $\beta$-lactam. Since, Elores demonstrated low $\mathrm{Vmax} / \mathrm{Km}$ ratio indicating low affinity

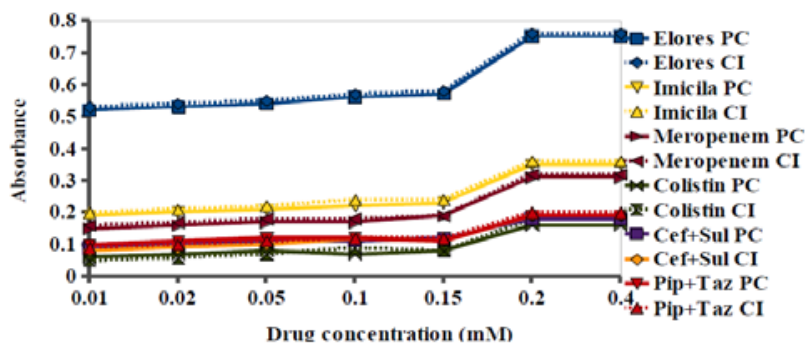

Higher absorbance indicating higher drug stability towards ESBL enzyme produced by $E$. coli clinical isolates.

Figure 1: Comparative $V_{\text {intac }} N_{\text {sonicated }}$ at different concentrations of drugs.

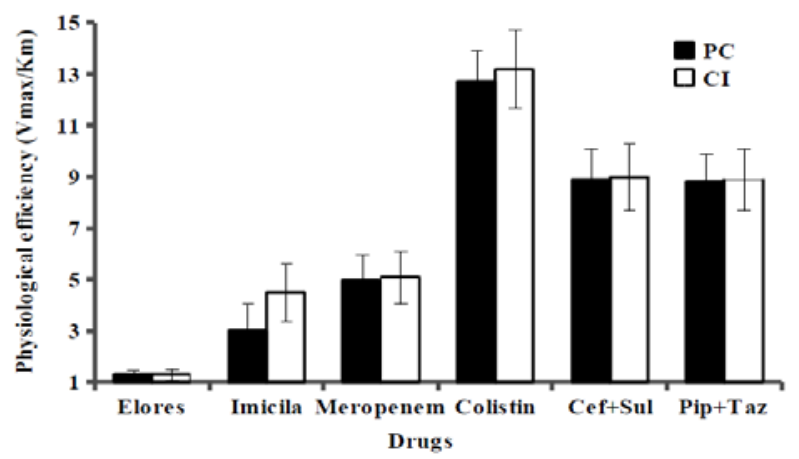

Figure 2: Comparative physiological efficiency of drugs. towards $\beta$-lactamase degradation or more stability against $\beta$-lactamase enzyme. Imipenem plus cilastatin, meropenem, colistin, cefoperazone plus sulbactam and piperacillin plus tazobactam exhibited 3.4, 3.9, 10.1, 6.9 and 6.8 folds higher $V \max / \mathrm{Km}$ ratio indicating very high affinity for $\beta$-lactamase when analyzed with ESBl producing resistant E. coli clinical isolates. Similar, observations were noted for positive control as well (Figure 2).

\section{Outer membrane permeability studies}

The rate of penetration of antibiotics across the outer membrane of gram negative bacteria is a key factor to exhibit their antibacterial activity. The antibiotics having less penetration may not reach appropriate concentration to neutralize their targets and get inactivated by bacterial enzymes during transit $[6,9]$. The non antibiotic adjuvant EDTA present in Elores facilitates removal of the divalent ions of bacterial cell membrane thus causing alteration in bacterial membrane permeability resulting in increased penetration of ceftriaxone and sulbactam inside the bacterial cells. This increased penetration leads to higher periplasmic concentration of the drug. The antibiotics with high periplasmic concentration exhibit high $\beta$-lactamase $\mathrm{Km}$, while those with low periplasmic concentration shared high affinity (low $\mathrm{km}$ ) for $\beta$-lactamase. This is consistent with the study conducted by Bellido et al. [20]. The periplasmic concentration attained by the Elores in comparison to penem products was 3-4 times higher in resistant $E$. coli clinical isolates. The antibiotics demonstrating high permeability coefficient and periplasmic concentration showed higher susceptibility compared to the antibiotics showing less permeability coefficient and low periplasmic concentration. Other BL+BLI combinations achieved $>7$ times lower periplasmic concentrations than Elores indicating lesser penetration in bacterial cell and hence less activity. Colistin, an old molecule with high toxicity which was revived due to scarcity of antibiotics responding to resistant strains, achieved more than 29 times lower concentration which clearly indicates the failure of colistin activity against resistant E. coli strains (Table 2). Our results clearly demonstrate that the Elores shows the least MIC values $(1-2 \mu \mathrm{g} / \mathrm{ml})$ due to higher periplasmic concentration followed by imipenem plus cilastatin, meropenem, cefoperazone plus sulbactam, piperacillin plus tazobactam and colistin. The low penetration of other drugs results in a relatively lower rate of uptake of $\beta$-lactam antibiotics into the periplasm and consequently decrease efficacy of these antibiotics to bacterial cells. These results are in agreement with the earlier study [20]

Further our results revealed that Elores penetrated the outer membrane of E. coli with permeability coefficient approximately 1.8 , 2.2, 6.9, 2.5 and 2.3 times higher than imipenem plus cilastatin and meropenem, colistin, cefoperazone plus sulbactam, piperacillin plus tazobactam, respectively (Figure 3). The enhanced penetration and stability against beta-lactamase of Elores is due to synergistic activity of ceftriaxone plus sulbactam and presence of non antibiotic adjuvant ethylenediamine tetraacetic acid (EDTA) [21,22].

\section{Conclusion}

The study, conducted under EASE programme, provides a fairly good trend of different antibiotics against ESBL producing E. coli clinical isolates collected from Delhi NCR hospitals including public and private ones. The most significant observation of this study was the enhanced penetration and greater stability of Elores, the novel antibiotic adjuvant entity, when compared with other tested drugs including penems and $\beta$-lactam plus $\beta$-lactamase combinations. Therefore, Elores can be considered as a drug of choice for the treatment of resistant ICU 


\begin{tabular}{|l|c|c|c|c|}
\hline \multirow{2}{*}{ Drugs } & \multicolumn{2}{|c|}{ MIC $(\boldsymbol{\mu g} / \mathrm{ml})$} & \multicolumn{2}{c|}{$\begin{array}{c}\text { Periplasmic concentration } \\
(\boldsymbol{\mu M})\end{array}$} \\
\cline { 2 - 5 } & $\begin{array}{c}\text { Positive } \\
\text { control }\end{array}$ & $\begin{array}{c}\text { Clinical } \\
\text { isolates }\end{array}$ & $\begin{array}{c}\text { Positive } \\
\text { control }\end{array}$ & Clinical isolates \\
\hline Elores & 1 & $1-2$ & $59.1 \pm 5.4$ & $58.2 \pm 5.7$ \\
\hline Imipenem plus cilastatin & 4 & $4-8$ & $18.1 \pm 1.6$ & $17.9 \pm 1.7$ \\
\hline Meropenem & 4 & $4-8$ & $14.2 \pm 1.4$ & $13.6 \pm 1.2$ \\
\hline Colistin & 16 & $16-32$ & $2.2 \pm 0.4$ & $2.0 \pm 0.5$ \\
\hline Cefoperazone plus sulbactam & 16 & $16-64$ & $7.8 \pm 1.1$ & $7.4 \pm 1.0$ \\
\hline Piperacillin plus tazobactam & 16 & $16-64$ & $8.6 \pm 1.0$ & $8.1 \pm 1.0$ \\
\hline
\end{tabular}

Table 2: MIC and periplasmic concentration of various drugs into $E$. coli.

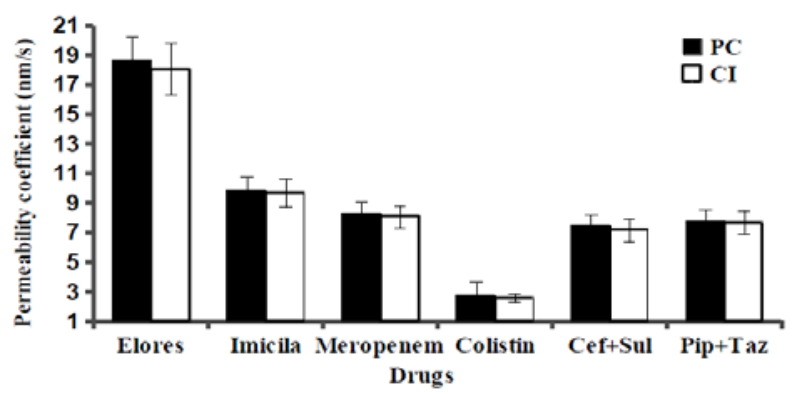

Figure 3: Comparative permeability coefficient of drugs.

infections caused by E. coli positive with ESBL. The study highlights the reason for non performance of most of the ICU drugs and provides a thought platform to envision and realize the importance of antibiotic stewardship and rationale use of penems.

\section{Acknowledgements}

Authors are thankful to sponsor, Venus Medicine Research Centre, Werne, Germany, for providing assistance to carry out this study. Also thank to institute which provided strains.

\section{References}

1. Gold HS, Moellering RC (1996) Antimicrobial drug resistance. N Eng J Med 335: 1445 .

2. Bradford PA (2001) Extended-spectrum $\beta$-lactamases in the 21st century: characterization, epidemiology, and detection of this important resistance threat. Clin Microbiol Rev 14: 933-951.

3. Medeiros AA (1997) Evolution and dissemination of $\beta$-lactamases accelerated by generation of $\beta$-lactam antibiotics. Clin Infect Dis 24: S19-S45.

4. Lakaye B, Dubus A, Joris B, Frere JM (2002) Method for estimation of low outer membrane permeability to beta-lactam antibiotics. Antimicrob Agents Chemother 46: 2901-2907.

5. Hancock RE, Wong PG (1984) Compounds which increase the permeability of the Pseudomonas aeruginosa outer membrane. Antimicrob Agents Chemother 26: $48-52$.

6. Chapman JS, Georgopapadakou NH (1987) Outer membrane penetration by (2,3)-methylenepenams. Antimicrob Agents Chemother 31: 1994-1996.

7. Nikaido H, Nakae $T$ (1979) The outer membrane of gram negative bacteria Adv Microb Physiol 20: 163-250.
8. Martínez-Martínez L, Hernández-Allés S, Albertí S, Tomás JM, Benedi J, Jacoby GA (1996) In vivo selection of porin-deficient mutants of Klebsiella pneumoniae with increased resistance to cefoxitin and expanded-spectrumcephalosporins. Antimicrob Agents Chemother 40: 342-348.

9. Nestorovich EM, Danelon C, Winterhalter M, Bezrukov SM (2002) Designed to penetrate: Time-resolved interaction of single antibiotic molecules with bacterial pores. PNAS, 99: 9789-9794.

10. Basle A, Rummel G, Storici P, Rosenbusch JP, Schirmer T (2006) Crystal

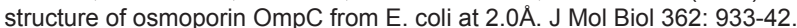

11. Jeanteur D, Lakey JH, Pattus F (1994) The porin superfamily: diversity and common features, p. 363-380. In J.-M. Ghuysen and R. Hakenbeck, (ed) bacterial cell wall. Elsevier, Amsterdam.

12. Hancock REW, Bell A (1988) Antibiotic uptake into gram negative bacteria. Eur $\mathrm{J}$ Clin Microbiol Infect Dis 7: 713-720.

13. Nikaido H, Vaara M (1985) Molecular basis of outer membrane permeability. Microbiol Rev 49: 1-32.

14. Ananthan S, Subha A (2005) Cefoxitin resistance mediated by loss of a porin in clinical strains of Klebsiella pneumonia and Escherichia coli. Indian J Med Microbiol 23: 20-23.

15. Bergeys DH, Buchanan RE, Gibbons NE (1975) Bergey's manual of determinative bacteriology. Baltimore, Williams \& Wilkins Company.

16. Clinical and Laboratory Standards Institute (CLSI) (2009) Performance standards for antimicrobial susceptibility testing, 19th informational supplement CLSI document M100-S19, Wayne, PA: CLSI, 29.

17. Novick RP (1962) Micro-iodometric assay for penicillinase. Biochem J 83: 236 240 .

18. Zimmermann W, Rosslet A (1977). Function of the outer membrane of Escherichia coli as a permeability barrier to beta-lactam antibiotics. Antimicrobial Agents Chemother 12: 368-372.

19. Lowry OH, Rosebrough NJ, Farr AL, Randall RJ (1951) Protein measurement with the Folin phenol reagent. J Biol Chem 193: 265-275

20. Bellido F, Pechere JC, Hancock REW (1991) Reevaluation of the factors involved in the efficacy of new $\beta$-lactams against Enterobacter cloacae. Antimicrob Agents Chemother 35: 73-78.

21. Chaudhary M, Payasi A (2012) Prospective Study for Antimicrobial Susceptibility of Escherichia coli isolated from various clinical specimes in Indian. J Microb Biochem Technol 4: 157-160.

22. Chaudhary M, Payasi A (2012) Role of EDTA and CSE1034 in curli formation and biofilm eradication of Klebsiella pneumoniae: a comparison with othe drugs. The J Antibio 65: 631-633. 